160.

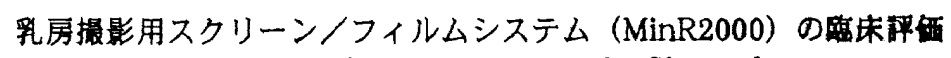

Clinical evaluation of new mammography film and screen system ; MinR2000

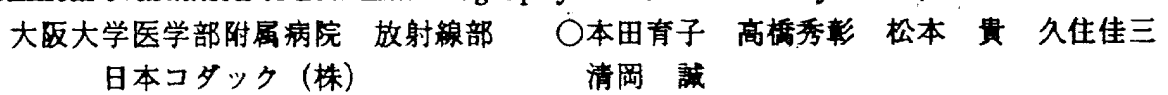

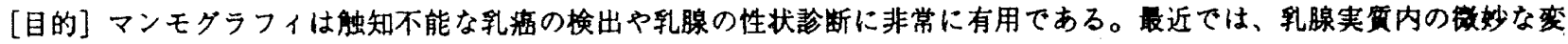
化や病変を的確に描出するため、高コントラストタイプのスクリーン/フィルムシステムが開発され、使用される㑯向にあ る。乳鬼検診の萁入にあたっては、より高感度で高画德のスクリーン/フィルムシステムが望まれている。

今回、コダック社が開発した高感度离コントラストタイブのスクリーンノフィルムシステム、（MinR2000スクリーンノ MinR2000フィルム) を使用する機会を得たのて、その物理特性並びに䠦床部洒について報告する。

[方法] 新システム（MinR2000スクリーン/MinR2000フィルム）と従来システム（MinRスクリーン／MinRMフィル

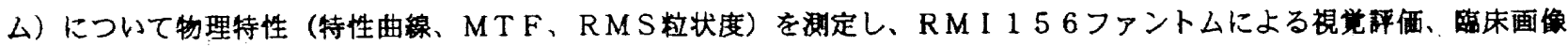
による評価を行った。

[結果] 新システムは従来システムに比べ、低湍度部から高湍度部にかけて高コントラストを稚持しており、特に低港度部 のコントラストの改茾が見られる。また、鲜鋭度、粒状性を劣化させることなく、高感度化も達成されている。RMIファン

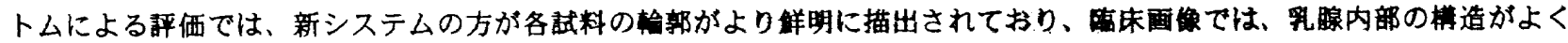
涀察でき、微小石灰化の描出にも優れていた。

161.

\title{
左室造影における容量解析の変動要因 〜計測者間,計测者内ての比较〜
}

Factors of variability in determining cine anglographic left.ventricular volumetry .

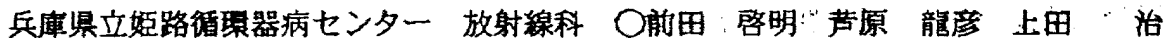
吉野 太司“金川 達也石本”叫在正明

【目的】左室造影における容量解析（以下LVV）の変動要因を検討する。

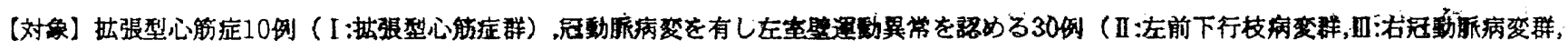
IV:左回族枝病変群，各々10例）。

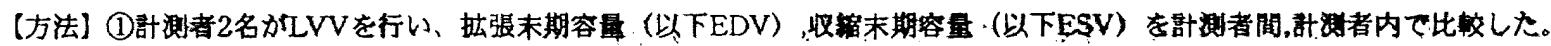

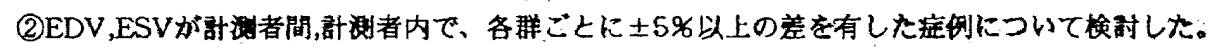

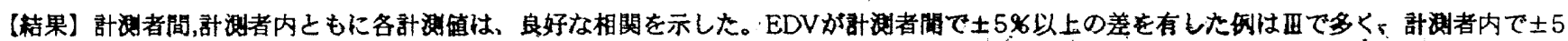

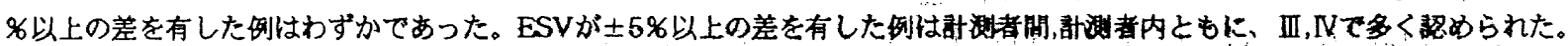

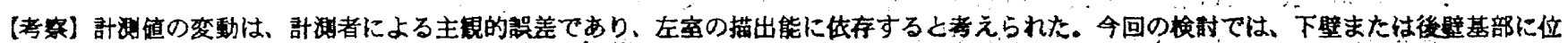

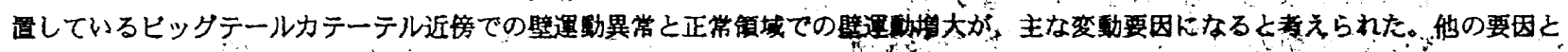

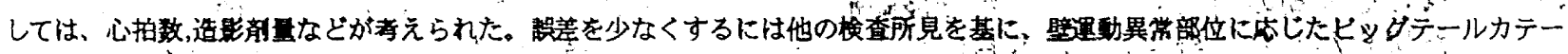
テルの位罟，向きの設定が必要と思われる。

162.

シネ撮影置機種間でのシネ画像のコントラストの比較

Comparision of contrast in cineradiograph among cine angiographic systems

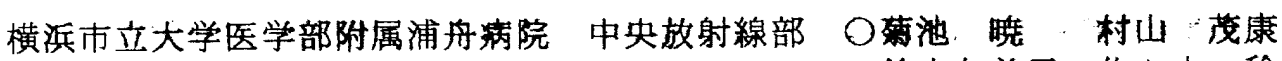
鉿木久美子 佐々木 稔

昭和大学病院 中央放射線部加藤 京一 中澤 靖夫

横浜労災病院 放射線部萩原 充人 佐藤 律夫

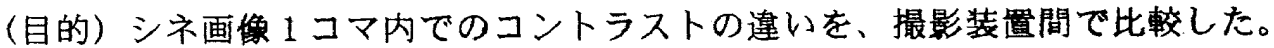

（方法） 1 ．異なるシネ撮影装置で、一定の撮影条件下で鉰板を $0.25 \mathrm{~m}$ ３.0 mまで変化させ、全面露光での I.1.入射線量とフィルム露光面での輝度を測定した。

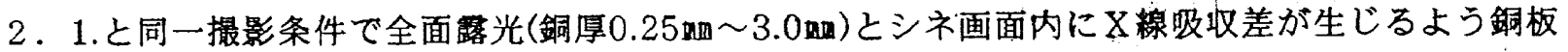
を配置したものをシネ撮影し、両者のフィルム漶度を比較した。

(結果) 入射線量と輝度の関係は、各装置とも直線性を示した。1コマ内でX線吸収差を生じさせた場合の フィルム濃度は、全面露光の同一銅厚のフィルム濃度に比べ変化し、その程度は装置間で異なって ゆた。 